\title{
Determinants of Migrants' Savings in the Host Country: Empirical Evidence of Migrants living in South Africa
}

\author{
Daniel Makina \\ University of South Africa, South Africa \\ makind@unisa.ac.za
}

\begin{abstract}
The paper uses a data set of Zimbabwean migrants living in South Africa to investigate the saving behaviour they exhibit in the host country. Having observed that these migrants comprise those that do save in the host country and those that do not save at all, the paper employs a Tobit function that is capable of modelling the savings level as function of migrant characteristics. The results observed are that the level of migrant savings in the host country is positively related to migrant income level, return migration intentions, number of dependents in the host country, remittance level and access to banking services, and is negatively related to the age of the migrant, number of dependents in the home country, migrant length of stay, migrant legal status, and frequency of home visits. Interestingly, the savings behaviour of migrants in the host country mirrors the remittance behaviour in many respects.
\end{abstract}

Keywords: Migrant savings; remittances; return migration; South Africa; Zimbabwe

\section{Introduction}

In the migration literature the saving and remittance behaviours of migrants are not easily separable. In fact most studies consider migrant savings and remittances as substitutes or products of joint decisions. A migrant could send home remittances as savings. Alternatively, a migrant could save temporarily in the host country in anticipation of remitting home such savings. Hence, some researchers allude to these transfers as savings-related remittances (Merkle and Zimmermann, 1992; Bauer and Sinning, 2011). Economic literature analyses individual savings behaviour using the expected utility model whereby agents are assumed to be rational and who strive to maximize lifetime utility. More often empirical studies have largely focused on individuals who spend their lifetime in one location and the saving behaviour of migrants has been assumed to be the same as that of citizens (MaCurdy et al., 1998). While researchers such as Dustmann (1997), Galor and Stark (1990) and Carroll et al., (1994) have observed that migrants often exhibit savings behaviour different from that exhibited by citizens, very little empirical work has been undertaken to investigate this phenomenon. More recently, Sinning (2011) observes that a few studies have invested migrants' savings and remittances jointly. Understanding factors that determine savings accumulation by migrants is important for both the host country and the home country. For the host country, an aging migrant population that has been saving alleviates potential social security support from the state. Furthermore, migrant savings in the host country motivate return migration (Djajic, 1989; Dustmann, 1997, 2003; and Stark et al., 1997). For the home country, migrants who would have accumulated savings in the host country invest in businesses upon return, and are also not a social burden to the state. This paper contributes to the body of knowledge on empirical work that focuses on the determinants of migrants' savings in the host country rather than in the home country. The empirical findings reveal that the level of migrant savings have a significant positive relationship with migrant income level, return migration intentions, number of dependents in the host country, remittance level and access to banking services. On the other hand, a negative relationship is found with the age of the migrant, number of dependents in the home country, migrant length of stay, migrant legal status, and frequency of home visits. The rest of the paper is structured as follows. Section 2 discusses the methodology used. Section 3 discusses empirical results. Finally, section 4 concludes.

\section{Literature Review}

Sinning (2011) observes that economic literature on the performance of migrants in the host country largely concentrates on the analysis of their earnings and employment status. However, there are few studies that have investigated the wealth accumulation behaviour of migrants in their home countries (Amuedo-Dorantes and Pozo, 2006). Amuedo-Dorantes and Pozo (2006) observe that migrants remit for 
family-provided insurance and for self-insurance. Research on migrant savings in the host country is still sketchy and has largely focused on savings in the context of return migration. Borjas (1994), for instance, explains return migration as part of optimal life-cycle location decisions whereby a migrant only stays in the host country for the purposes of accumulating savings and human capital. Contrary to this view, Merkle and Zimmermann (1992) who investigated the savings of migrants in the host country Germany and their remittances abroad, observed that return intentions influence remittances but do not influence migrant savings behaviour. On the other hand, Bauer and Sinning (2011) who investigated migrant savings in both the home and host country, observed that migrants staying temporarily in Germany save significantly more than permanent migrants. Emerging empirical evidence suggests a savings accumulation motive for migration (Kirdar, 2009; Dustmann and Kirchkamp, 2002; Kumcu, 1989). Kirdar (2009) confirms the view of Borjas (1994) that return migration is part of optimal life-cycle location decisions where migrants return when the marginal benefit of higher savings falls below the marginal cost of staying. Dustmann and Kirchkamp (2002) reported Turkish returnees from Germany having a savings motive after observing that only $6 \%$ of returnees worked as salaried workers; $51 \%$ were selfemployed; and the other $43 \%$ were retired. Kumcu (1989) observed higher savings rate in the host country among Turkish migrants compared with native-born Germans, and thus confirming the savings motive for migration.

Employing mathematical modelling, Galor and Stark (1990) have demonstrated that migrants who face a positive probability of return migration save more than locals, a result that is consistent with the lifecycle theory of consumption in that those migrants who expect a lower future income (in the home country) than their current income (in the host country) must save more to smooth their consumption path over their life-cycle. Assuming that migrants maximize expected lifetime utility proportionally to the lifetime spent in the host country and at home, Dustmann (1997) shows that if labour markets in the home and host countries are not correlated, migrants would undertake more precautionary savings in the host country relative to the citizens. The reason for this behaviour is that migrants would be subject to greater income risk in the host country. Extending Dustmann's economic model, Amuedo-Dorantes and Pozo (2002, p. 49) demonstrate that it also possible for migrants to engage in less precautionary saving relative to citizens for two reasons. First, if the economic conditions in the home and host countries are correlated, migrants might have less lifetime income risk than citizens as they would be able to diversify away labour market risk by operating in two markets unlike citizens. Second, they postulate that if the risk preferences of citizens and migrants are different, the precautionary saving motive could also be different in one group relative to the other, ceteris paribus. Using the Canadian Survey of Family Expenditures, Carroll et al. (1994) compared the saving behaviour of migrants to Canada by country of origin and found that saving behaviour does not differ by country of origin. That notwithstanding, they found that recent migrants save less than Canadian-born citizens and that over time the pattern of saving behaviour of migrants becomes the same as that of Canadian-born citizens.

Using the 1979 Youth Cohort of the National Longitudinal Surveys of the USA, Amuedo-Dorantes and Pozo (2002) investigated the wealth accumulation patterns of younger cohorts and how they differ across USA-born citizens and migrants. They found that on average migrants save less as compared to USA-born citizens, and thus supporting Amuedo-Dorantes and Pozo's (2002) argument that migrants might save less because of their different opportunities to diversify away economic risk. Demographic characteristics such age, gender, education and the employment status have been observed to explain both migrant savings and remittances (Cox et al., 1998; del la Briere et al., 2002; Merkle and Zimmermann, 1992). With regard to migrant savings, the focus has been largely remittance-related savings, i.e. savings in the home country, rather than savings in the host country. A recent study by Sinning (2011) that analysed the determinants of migrant savings in the home country identified the following factors: age, gender, household size, income, education, return intentions, length of stay and country of origin. Age is observed to influence migrant savings as evidence of an inverted $U$-shaped age profile consistent with the intertemporal consumption model is found. On average women are found less likely to send savings to their home country. Income is found to be positively related to migrants' savings. Migrants who attended school in the host country are observed to exhibit higher savings. Married migrants save more in their home country, while the presence of children in the household is not found to influence savings and other transfers abroad. Migrants who intend to return are observed to exhibit higher savings in the home country than those intending to settle in the host country. Interestingly, Sinning (2011) finds the duration of stay in the host country Germany to be a weak predictor of migrants' savings in their home country. 
While this paper utilises migrant savings predictor variables as those used by Sinning (2011) and others, its approach differs in several respects. First, the paper focuses on migrant savings in the host country rather than those send home using data of Zimbabwean migrants living in South Africa. Second, the savings and remittance decisions are viewed as joint decisions in all the above earlier studies. Crucially, the level of remittances sent abroad is treated as a predictor of the level of migrant savings in the host country. In other words, the level of remittances sent to the home country is seen as an independent variable of the dependent variable -level of migrant savings in the host country. Thus, in the paper the level of migrant savings in the host country is hypothesized to be a function of the level of remittances sent home, plus other migrant characteristics identified in the literature, viz.:

- Length of stay in the host country;

- Legal status in the host country;

- Gender;

- Age;

- Marital status;

- Education level;

- Access to banking services in the host country;

- Income level;

- Number of dependents supported in the host country;

- Number of dependents supported in the home country;

- Frequency of home visits; and

- Return migration intentions.

Prior research on this same dataset of Zimbabwean migrants living in South Africa utilized in this paper has elicited several insights. One study identified six factors -reason for migrating, the number of dependents supported in the home country, the level of education, economic activity in the host country, the level of income and the duration of stay in the host country - are found to be statistically significant determinants of the return migration intention (Makina, 2012).Another study observed that financial access of migrants to be positively related to legal status, income level, savings level and education level (Makina, 2013).

\section{Methodology}

We use cross-sectional data from a survey of Zimbabwean migrants living in South Africa conducted in 2007 and reported by Makina (2010). The survey captured data on remittances, income, savings, demographic and socio-economic characteristics of over 4000 Zimbabwean migrants who arrived in South Africa from 1979 to 2007. The data utilized comprised migrants who indicated zero amounts of savings (50\% of sample) and those who indicated various levels of savings (50\% of sample) in the host country. Savings levels are thus a mixture of discrete and continuous distributions. This censored nature of the distribution of savings renders the utilization of OLS inappropriate if both savers and non-savers are to be jointly analysed. Hence, a Tobit model which can handle censored data is employed for analysis. We proceed by taking migrant savings to be a function of age, gender, marital status, education level, number of dependents supported in the host country, number of dependents supported in the home country, income level, remittance level, access to banking services, legal status, length of stay, return migration intentions and frequency of home visits. Then consistent with earlier research dealing with censored data, a conventional Tobit model that is capable of modelling the savings level as function of migrant characteristics is utilized (Sinning, 2011; Merkle and Zimmermann, 1992). The level of migrant savings is thus given by the following equation:

$\mathrm{R}_{\mathrm{i}}=\alpha \mathrm{t}_{\mathrm{i}}+\beta \mathrm{t}_{\mathrm{i}}^{2}+\mathrm{X}_{\mathrm{i}} \varphi+\varepsilon_{\mathrm{i}}$, with $\mathrm{R}_{\mathrm{i}}=\max \left(0, \mathrm{R}_{\mathrm{i}}\right)$

Where:

- $\mathrm{R}_{\mathrm{i}}$ is a vector of the rand amount saved (recognising that some migrants save 0 rands and others save real rand amounts, thus giving a combination of discrete and continuous distributions);

- $t_{i}$ is the time spent living in South Africa;

- $t_{i}{ }^{2}$ is a squared term of time spent living in South Africa which captures a linear or non-linear pattern in savings behaviour;

- $\mathrm{X}_{\mathrm{i}}$ is vector of migrant characteristics; and

- $\varepsilon_{\mathrm{i}}$ is the error term. 
If the pattern of savings of a migrant first follows an upward trend and then a downward trend over time (i.e. hump-shaped), the coefficient of $t_{i}$ would be positive and that of $t_{i}{ }^{2}$ would be negative. Such behaviour would be inimical to that of remittances in the context of the decay hypothesis. The vector of migrant characteristics comprises twelve explanatory variables, viz. age, gender, marital status, number of dependents in the host country, number of dependents in home country, education level, income level, access to banking services, legal status, return migration intentions, frequency of home visits and remittance level whose expected coefficient signs are discussed below.

Age: If the coefficient is negative it means than the younger migrant is savings more than the older migrant. Such a situation would be consistent with Ando and Modigliani (1963)'s life-cycle hypothesis of consumption. The hypothesis stipulates that the amount of saving in a society depends upon the birth rate and death rate because these two factors affect the proportion of the population that is at a saving stage of the life-cycle and the proportion that is dis-saving.

Gender: An investigation on gender effects on aggregate saving by Floro and Seguino (2002, p.39) found evidence that is consistent with "the hypothesis that an increase in women's discretionary income and bargaining power raises household saving and therefore aggregate saving rates". As to whether migration has an effect on gender saving behaviour is an open question. However, in the context of savings sent abroad, Sinning (2011) observes that female migrants are less likely to send savings to their home country. Assigning binary $1=$ Male and $0=$ Female, a negative coefficient would mean males have lower savings level than females in the host country and vice versa if coefficient is positive.

Marital Status: Young unmarried migrants could be expected to save more than the older married migrants. Indeed, Massey and Basem (1992) observe that married migrants with dependents tend to remit larger shares of their income back to their families and save less. Giving a binary $1=$ Married and 0 = Single, a positive coefficient would indicate that single migrants are saving more than married migrants in the host country and vice versa if the coefficient is negative.

Education level: The expectation is that the higher the education level a migrant has the more the savings by virtue of the fact higher education attracts higher earnings. Giving education level a binary of $1=$ Primary and $0=$ Other (secondary or tertiary), a positive coefficient would mean migrants with higher education level save more than those with primary education while a negative coefficient would indicate the opposite.

Income level: From the premise that savings are a function of income, the higher the income the more the savings a migrant would make. This is essentially a stylized fact.

Number of dependents supported in the host country: The expectation is that a migrant who has migrated with most of his/her family members is likely to save more in the host country. Hence, the expected coefficient of this variable is positive.

Number of dependents supported in the home country: The expectation is that a migrant who has left most of his/her family members in the country of origin will save less in the host country. The migrant may have to remit most of income to support dependents left home. The expected coefficient of this variable is therefore negative.

Legal status: The expectation is that migrants that are undocumented will find it difficult to access financial services in the host country (Makina, 2013). Therefore, giving binary 1=Undocumented, $0=$ Documented, if the coefficient of the legal status variable is negative it means than undocumented migrants will be save less than documented migrants in the host country. The possibility is that due to fear of deportation, they are unlikely to be much saving in the host country. In any case they are unlikely to have the required documentation for opening savings accounts in the host country.

Return migration intention: An analysis by Galor and Stark (1990) demonstrates positive probability of return migration results in migrants saving more than host country citizens. Empirical work by Bauer and Sinning (2011) reveal that "intended return migration does not only affect remittances, but also the savings rate of migrant households in the host country". Therefore, given binary $0=$ return, $1=$ settling in 
South Africa, if the coefficient is positive it means that migrants who intend to return save more compared to those who intend to settle in the host country.

Frequency of home visits: Frequent visits may be an indication of a strong attachment to the home country and maybe possibly influencing the choice of place to save part of a migrant's earnings. All other things being equal (especially investment returns), a migrant who makes frequent home visits is likely to save in the home country in which case if the coefficient is negative it means that a migrant who goes home often would save less in the host country compared to a migrant who does not go home often.

Remittance level: Having remittances as an explanatory variable of savings is a departure from prior literature that generally views the two as substitutes. As earlier explained in this paper, it is hypothesized that the remittance level is a predictor of the migrant savings level in the host country. The coefficient could be either positive or negative. If the coefficient is positive it means that a high remittance level reinforces more savings. On the other hand, as pointed out by Merkle and Zimmermann (1992), remittances can also be viewed as a form of savings if a migrant has an intention of return migration in which case the coefficient could be negative.

Access to banking services: It is long established that access to financial services influence saving choices. Therefore, the expectation is that a migrant with access would save more than one without access. The sign of this variable is therefore expected to be positive.

\section{Data Analysis and Findings}

Cognizant of the cross-sectional type of data and its censored nature, Tobit regression is employed and the results obtained are in Table 1 below.

Table I: Tobit Model: Dependent Variable is the Annual Amount of Rands saved by Migrant

\begin{tabular}{|c|c|c|}
\hline Explanatory variable & Tobit Coefficient & t-statistic \\
\hline Constant & -36.12 & -0.06 \\
\hline Length of stay & $-104.87^{* * *}$ & -2.58 \\
\hline Length of stay squared & $4.2^{* *}$ & 2.02 \\
\hline Legal status $((1=$ Undocumented, $0=$ Documented $)$ & $-315.67^{* *}$ & -2.38 \\
\hline Gender ( 1 = Male, 0 = Female $)$ & 154.83 & 1.22 \\
\hline Age & $-2851.41^{* *}$ & -2.14 \\
\hline $\begin{array}{l}\text { Marital status }(0=\text { Single, } 1=\text { Married and } \\
\text { other })\end{array}$ & 48.34 & 0.55 \\
\hline Education level ( $0=$ Other, 1 = Primary $)$ & 182.70 & 0.56 \\
\hline Access to banking services & $3175.10^{* * *}$ & 22.44 \\
\hline Level of income & $0.04^{* * *}$ & 14.80 \\
\hline Dependents in host country & $249.04^{* * *}$ & 2.64 \\
\hline Dependents in home country & $-470.44^{* * *}$ & -5.69 \\
\hline Frequency of home visits & $-74.63^{* * *}$ & -7.43 \\
\hline $\begin{array}{l}\text { Return migration intention }(0=\text { Intending to } \\
\text { return, } 1=\text { Settling in host country) }\end{array}$ & $534.84^{*}$ & 1.89 \\
\hline Level of remittances & $0.46^{* * *}$ & 12.10 \\
\hline $\mathrm{N}$ & 4183 & \\
\hline Left Censored Observations & 2031 & \\
\hline Uncensored Observations & 2152 & \\
\hline LR Chi2 (14) & 1853.71 & \\
\hline Log Likelihood & -21629.25 & \\
\hline
\end{tabular}

***, **, * Respectively significant at $1 \%, 5 \%$ and $10 \%$ level. 
The length of stay has significant negative coefficient meaning that the longer a migrant stay in the host country the less the saving level. This is in contrast with the suggestion by Bauer et al. (2007) that the length of stay in the host country could have positive effects on the savings of migrants. The difference could be a result of specific country effects as Bauer et al. (2007) investigated migrants living in Germany while this paper focuses on migrants living South Africa. The significant positive coefficient of the square of the length of stay shows that the savings are a linear function rather than non-linear. Legal status is found to significantly affect migrants' savings behaviour in the host country. The level of savings of undocumented migrants is lower than that of documented migrants. This finding is as expected because undocumented migrants have no access to financial services in the host country as reported by Makina (2013). They are likely to save in the home country via sending remittances. On the other hand, as expected access to banking services is found to a significant positive influence on migrant savings. The demographic factor, age, is found to significantly affect migrant savings. The younger the migrant is the higher the saving level and this behaviour is consistent with the life-cycle theory of consumption ${ }^{1}$. This finding is consistent with the observation by Bauer and Sinning (2011) for migrants living in Germany. Other demographic factors such as gender, marital status and education level are found not to significantly influence migrant saving behaviour in the host country.

As expected from economic theory, the migrant saving level is a positive function of the income level. The more a migrant earns the more he or she puts aside as savings in the host country. The number of dependents supported in the host country and in the home country is observed to significantly influence migrant savings in the host country. The more dependents a migrant supports in the host country, the higher the savings in the host country. On the other hand, the more dependents a migrant supports in the home country, the fewer savings are made in the host country. One explanation is that migrant who has been accompanied by most of the family members would having intention of settling and hence having higher savings in the host country whereas a migrant who has left family members home is likely to send most of income home as remittances. The level of remittances is found to be a significant positive predictor of migrant savings in the host country. Had the coefficient of the remittance variable been negative, it could have been an indication that migrants prefer saving in the home country via sending remittances. Frequent home visits are found to negatively influence saving levels in the host country. It is plausible to say that a migrant who visits home often might prefer saving in the home country. It can be argued that such a migrant would be having a greater attachment to the home country than a migrant who does not frequent the home country. Consistent with other empirical evidence, migrants with intentions to return home save more than those without who intend to settle in the host country (see also, Dustmann, 1997; Galor and Stark, 1990; Bauer and Sinning, 2011).

\section{Conclusion}

This paper contributes to a sparsely researched area regarding the determinants of migrants' savings in the host country. Its main findings are that the level of migrant savings is positively related to income level, number of dependents in the host country, return migration intentions, remittance level and access to banking services, and negatively related to the age of the migrant, length of stay, number of dependents in the home country, undocumented status, and frequency of home visits. These findings and those from literature show similarities between determinants of migrants' savings in the host country and determinants of remittances. Significantly, both are positively related to income level and access to banking services and negatively related to the age of the migrant. With regard to other characteristics they exhibit a diametrically opposite relationship.

\section{References}

Amuedo-Dorantes, C. \& Pozo, S. (2002). Precautionary Saving by Young Immigrants and Young Natives. Southern Economic Journal, 69(1), 48-71.

Amuedo-Dorantes, C. \& Pozo, S. (2006). Remittances as insurance: Evidence from Mexican immigrants. Journal of Population Economics, 19, 227-254.

\footnotetext{
${ }^{1}$ The variable age squared was not used because ages were entered in the Tobit regression as codes or dummies.
} 
Ando, A. \& Modigliani, F. (1963). The Life Cycle Hypothesis of Saving: Aggregate Implications and Tests. American Economic Review, 3, 55-84.

Bauer, T. K., Cobb-Clark, D. A., Hildebrand, V. A. \& Sinning, M. (2007). A Comparative Analysis of the Nativity Wealth Gap. Ruhr Economic Papers, 6, 1-52.

Bauer, T. K. \& Sinning, M. G. (2011). The Savings Behavior of Temporary and Permanent Migrants in Germany. Journal of Population Economics, 24, 421-449.

Borjas, G. J. (1994). The economics of immigration. Journal of Economic Literature, 32, 1667-1717.

Carroll, C. D., Rhee, B. \& Rhee, C. (1994). Are there cultural effects on saving? Some cross-sectional evidence. Quarterly Journal of Economics, 109, 685-699.

Cox, D., Eser, Z. \& Jimenez, E. (1998). Motives for private transfers over the life cycle: An analytical framework and evidence from Peru. Journal of Development Economics, 55, 57-80.

De la Briere, B. A., de Janvry, S. L. \& Sadoulet, E. (2002). The roles of destination, gender, and household composition in explaining remittances: An analysis for the Dominican Sierra. Journal of Development Economics, 68(2), 309-328.

Djajic, S. (1989). Migrants in a guest-worker system: a utility maximizing approach. Journal of Development Economics, 31, 327-339.

Dustman, C. (1997). Return migration, uncertainty and precautionary saving. Journal of Development Economics, 52, 295-316.

Dustmann, C. (2003). Return migration and optimal migration duration. European Economic Review, 47, 353-369.

Dustmann, C. \& Kirchkamp, O. (2002). The optimal migration duration and activity choice after remigration. Journal of Development Economics, 67,351-372.

Floro, M. S. \& Seguino, S. (2002). Gender Effects on Aggregate Saving. Working paper Series No. 23, World Bank Development Research Group/Poverty Reduction and Economic Management Network.

Friedman, M. (1957). A Theory of the Consumption Function. Princeton University Press: Princeton, N. J.

Galor, O. \& Stark, O. (1990). Migrants' Savings, the Probability of Return Migration and Migrants' Performance. International Economic Review, 31(2), 463-467.

Kirdar, M. G. (2009). Labor market outcomes, savings accumulation, and return migration. Labour Economics, 16, 418-428.

Kumcu, E. M. (1989). The savings behaviour of migrant workers: Turkish workers in W. Germany. Journal of Development Studies, 30, 273-286.

MaCurdy, T., Nechyba, T. \& Bhattacharya, J. (1998). An economic framework for assessing the fiscal impacts of immigration. In James P. Smith and Barry Edmonstron, eds., the immigration debate: Studies on the economic, demographic, and fiscal effects of immigration, Washington, D. C.: National Academy Press.

Makina, D. (2010). Zimbabwe in Johannesburg. In J. Crush and D. Tevera, eds., Zimbabwe's Exodus: Crisis, Migration, Survival, Southern African Migration Programme/IDRC 2010.

Makina, D. (2012). Determinants of return migration intentions: Evidence from Zimbabwe migrants living in South Africa. Development Southern Africa, 29(3), 365-378.

Makina, D. (2013). Financial Access for Migrants and Intermediation of Remittances in South Africa. International Migration, 51(s1), e133-e147.

Massey, D. S. \& Basem, L. C. (1992). Determinants of Savings, Remittances, and Spending among U.S. Migrants in Four Mexican Communities. Sociological Inquiry, 62(2), 185-207.

Merkle, L. \& Zimmermann, K. F. (1992). Savings, remittances, and return migration. Economic Letters, 38, 77-81.

Sinning, M. G. (2011). Determinants of Savings and Remittances: Empirical Evidence from Immigrants to Germany. Rev Econ Household, 9, 45-67.

Stark, O., Helmenstein, C. \& Yegorov, Y. (1997). Migrants' savings, purchasing power parity, and the optimal duration of migration. International Tax and Public Finance, 4, 307-304. 